\title{
Comparison of Physical and Mechanical Properties of Microwave-Polymerized Acrylic Resin after Disinfection in Sodium Hypochlorite Solutions
}

\author{
Helena de Freitas Oliveira PARANHOS \\ Letícia Resende DAVI \\ Amanda PERACINI \\ Rafael Bellini SOARES \\ Cláudia Helena da Silva LOVATO \\ Raphael Freitas de SOUZA \\ Department of Dental Materials and Prosthodontics, Dental School of Ribeirão Preto, \\ University of São Paulo, Ribeirão Preto, SP, Brazil
}

\begin{abstract}
This study evaluated the color stability, surface roughness and flexural strength of a microwave-polymerized acrylic resin after immersion in sodium hypochlorite $(\mathrm{NaOCl})$, simulating $20 \mathrm{~min}$ of disinfection daily during 180 days. Forty disk-shaped (15 x $4 \mathrm{~mm})$ and 40 rectangular $(65 \times 10 \times 3 \mathrm{~mm})$ specimens were prepared with a microwave-polymerized acrylic resin (Onda-Cryl). Specimens were immersed in either $0.5 \% \mathrm{NaOCl}, 1 \% \mathrm{NaOCl}$, Clorox/Calgon and distilled water (control). Color measurements were determined by a portable colorimeter. Three parallel lines, separated by $1.0 \mathrm{~mm}$, were registered on each specimen before and after immersion procedures to analyze the surface roughness. The flexural strength was measured using a 3-point bending test in a universal testing machine with a $50 \mathrm{kgf}$ load cell and a crosshead speed of $1 \mathrm{~mm} / \mathrm{min}$. Data were analyzed statistically by ANOVA and Tukey's test $(\alpha=0.05)$. There was no statistically significant differences $(p>0.05)$ among the solutions for color, surface roughness and flexural strength. It may be concluded that immersion in $\mathrm{NaOCl}$ solutions simulating short-term daily use during 180 days did not influence the color stability, surface roughness and flexural strength of a microwave-polymerized acrylic resin.
\end{abstract}

Key Words: microwave-polymerized acrylic resin, sodium hypochlorite, color stability, surface roughness, flexural strength.

\section{INTRODUCTION}

Denture cleansing is indispensable for general health of edentulous people. However, cleansing can be a challenge for elderly patients who cannot adequately brush their dentures because of disease, dementia and poor dexterity. Among the several available methods, soaking in sodium hypochlorite $(\mathrm{NaOCl})$ diluted in water has been indicated for complete denture hygiene (1). This method is effective in reducing Candida albicans in patients with denture-induced stomatitis (2), depending on the concentration and the immersion time. However, the immersion in chemical solutions should not alter the physical properties of the denture base resins.
Denture base polymers are susceptible to color shifting as a consequence of the incorrect use of cleansing solutions (3). Factors such as high temperature of the water used for soaking can cause some degree of whitening (4). Similarly, chemical products, such as hot alkaline peroxide solutions, produce elevated water sorption, which causes a surface whitening that is not reversible after desiccating (5).

Topographical changes represent other form of possible damage on denture base acrylic resin. Irregularities and porosities present on denture surfaces offer a favorable niche to retain stain and bacterial biofilm (6). Surface roughness present clinical relevance since it can affect the biofilm formation or makes its removal 
difficult (7). Certain chemical products are known to increase surface roughness. Ma et al. (8) observed that the phenolic-based disinfectants are able to cause surface damage to 5 resins after $30 \mathrm{~min}$ of immersion.

Chemical products can also alter bulk properties of denture bases. Immersion in denture cleansers and disinfecting solutions may decrease the flexural strength of acrylic resins (9). Robinson et al. (4) reported that denture base resins treated with hypochlorite had presented reduced flexural strength in association with whitening. This property is strongly related with clinical longevity of complete dentures, so it should not be significantly influenced by denture cleansing methods. Adecrease in denture base acrylic resin flexural strength can result in greater fracture incidence by impact or occlusal forces $(10,11)$.

$\mathrm{NaOCl}$ solutions have been used for a long time as denture cleansers and several regimens have been proposed (12-14). Nevertheless, the effect of those solutions on the properties of denture base acrylic resins can be influenced by some factors which were not still evaluated. Several studies assessed $\mathrm{NaOCl}$ as a disinfecting agent for dental clinics and laboratories to reduce cross-contamination of dentures, and used high concentrations during short terms $(3,9,15)$. Its use as a chemical denture cleanser would demand the study of lower concentrations during longer periods.

The aim of this study was to evaluate the color stability, surface roughness and flexural strength of microwave-polymerized acrylic resin after immersion in $\mathrm{NaOCl}$, simulating a 20 min daily use for 180 days. The hypothesis tested was that immersion in $\mathrm{NaOCl}$ solutions influences the color stability, surface roughness and flexural strength of microwave-polymerized acrylic resin.

\section{MATERIAL AND METHODS}

\section{Specimen Fabrication}

Disk-shaped wax patterns (Wilson; Polidental Ind Com Ltda, São Paulo, SP, Brazil) (15 x 4 mm) and polytetrafluoroethylene rectangular matrices $(65 \mathrm{x} 10 \mathrm{x}$ $3.3 \mathrm{~mm}$ ) were invested with type IV dental stone (Durone; Dentsply Indústria e Comércio Ltda., Petrópolis, RJ, Brazil) in plastic flasks. Forty specimens of each size were prepared of microwave-polymerized acrylic resin (Onda-Cryl; Artigos Odontológicos Clássico Ltda., São
Paulo, SP, Brazil). The resin was manipulated, packed, pressed into the mold and polymerized according to the manufacturer's instructions.

After polymerization of the resin, the specimens were removed from the molds and immersed in distilled water at $37 \pm 1^{\circ} \mathrm{C}$ for $50 \pm 2 \mathrm{~h}$ for residual monomer release. The excess resin was trimmed and one of the surfaces was finished using 180, 220, 360 and 400-grit sandpapers (Norton; Saint-Gobain Abrasivos Ltda., Guarulhos, SP, Brazil), and polished on a wet rag wheel with slurry of pumice followed by calcium carbonate. The polished specimens were marked with identifying codes and their dimensions were confirmed with a digital caliper (CD-6 - CSX-B; Mitutoyo Sul América Ltda, Suzano, SP, Brazil). Maximum tolerated differences between the dimensions of matrices and specimens were $\pm 0.2 \mathrm{~mm}$.

\section{Immersion Procedures}

The specimens were divided into 4 groups $(n=20$, 10 disks and 10 rectangular) and immersed in one of the following solutions: 1) $0.5 \% \mathrm{NaOCl}$ (Da Terra Farmácia de Manipulação, Ribeirão Preto, SP, Brazil); 2) $1 \% \mathrm{NaOCl}$ (Da Terra Farmácia de Manipulação); 3) Clorox solution $(5.25 \% \mathrm{NaOCl}$; The Clorox Company, Oakland, CA, USA) and Calgon water softener (sodium phosphates and sodium carbonate; Reckitt Benckiser, Pittsburgh, PA, USA) as described by Moore et al. (2). The Clorox/Calgon solution was prepared by mixing 1 teaspoon of Clorox solution and 2 teaspoons of Calgon in $250 \mathrm{~mL}$ of distilled water; 4) Distilled water (control group).

All the experiments simulated 20 min of daily immersion during 180 days (total time $=60 \mathrm{~h}$ ). Specimens were submitted to 180 immersion cycles (20 min each) at room temperature $\left(23 \pm 2^{\circ} \mathrm{C}\right)$. After each cycle, the soaking solution was discarded, and specimens were thoroughly washed in running water and dried with absorbent paper. A total of 45 cycles were performed daily. Specimens were immersed in distilled water at room temperature when the cycles were not carried out, regardless of the group.

\section{Color Analysis}

The 40 disk-shaped specimens were employed for color analysis. Color measurements were determined 
by a portable colorimeter (Color-guide 45/0; BYKGardner, Columbia, MD, USA), at the same side of the identifying codes on each disk-shaped specimen. Color changes $(\triangle \mathrm{E})$ were calculated with the use of CIELab color space. The CIELab is a color system representing three-dimensional color space with components of lightness (L), red-green (a), and yellow-blue (b).

The color differences $(\Delta \mathrm{E})$ between the measurements (before and after immersion in cleanser solutions), in terms of L, a, and b, were calculated from the following equation:

$\Delta E=\sqrt{(\Delta L)^{2}+(\Delta a)^{2}+(\Delta b)^{2}}$

in which $\Delta \mathrm{L}, \Delta \mathrm{a}$, and $\Delta \mathrm{b}$ are the differences of $\mathrm{L}$, $\mathrm{a}$, and $\mathrm{b}$ values before and after immersion.

To relate the color differences $(\Delta \mathrm{E})$ to a clinical environment, the color data were quantified by the National Bureau of Standards (NBS) units (12) through the formula NBS units $=\Delta \mathrm{E} \times 0.92$.

\section{Surface Roughness Test}

A surface analyzer (Surftest SJ-201P; Mitutoyo Corporation, Japan) was used to measure the surface roughness of each rectangular specimen before (baseline) and after immersion $(n=40)$. The resolution of the record data was $0.01 \mu \mathrm{m}$. The stylus moved across the specimen surface and 3 lines were recorded with a distance of $1 \mathrm{~mm}$ between each scanning line. The mean $R a$ was calculated from 3 lines as the mean roughness of the specimen. The roughness values before immersion were subtracted from the values after immersion to obtain the $\Delta \mathrm{Ra}$ (roughness difference).

\section{Flexural Strength Test}

Following roughness testing, rectangular specimens were immediately subjected to the flexural strength assessment. Flexural strength was measured using a 3-point bending test in a universal testing machine (Model DL 2000; EMIC, São José dos Pinhais, SP, Brazil) with a $50 \mathrm{kgf}$ load cell at a crosshead speed of $1 \mathrm{~mm} / \mathrm{min}$. The flexural strength (S) of each rectangular specimen was calculated using the following equation:

$S=\frac{3 P L}{2 b d^{2}}$

in which $\mathrm{P}$ is the maximum load, $\mathrm{L}$ is the distance between the supports, $\mathrm{b}$ is the specimen width, and $\mathrm{d}$ is the specimen thickness. Mean flexural strengths were calculated in $\mathrm{MPa}$.

\section{Statistical Analysis}

The $\Delta \mathrm{E}, \Delta \mathrm{Ra}$ and $\mathrm{S}$ values were subjected to statistical analysis by one-way ANOVA using the statistical program SPSS 12.0 (SPSS Inc., Chicago, IL, USA). All tests were performed using a confidence level of $95 \%$.

\section{RESULTS}

Table 1 presents the mean $\Delta \mathrm{E}$ values and standard deviations of each cleanser solution. No significant difference was found among the tested treatments $(p=0.395)$. The data of Table 1 were quantified by the National Bureau of Standards (NBS) units through the formula NBS units $=\Delta \mathrm{E} \times 0.92$. The mean $\Delta \mathrm{E}$ values for the solutions quantified by NBS were classified as 'Trace' $(0.0-0.5)$.

Results for $\Delta$ Ra tended to be near zero and flexural strength presented slight variation associated with the different groups (Table 1). No significant difference was found among treatments for $\Delta \mathrm{Ra}$ and flexural strength ( $p=0.822$ and 0.160 , respectively).

\section{DISCUSSION}

This study evaluated the color stability, surface roughness and flexural strength of microwave-polymerized acrylic resin submitted to short immersion in
Table 1. Characteristics of composite resins tested.

\begin{tabular}{lccc}
\hline Group & $\Delta \mathrm{E}$ & $\Delta \mathrm{Ra}$ & $\mathrm{S}$ \\
\hline 0.5\% Sodium hypochlorite & $0.29 \pm 0.07$ & $0.00 \pm 0.10$ & $91.77 \pm 15.71$ \\
1\% Sodium hypochlorite & $0.37 \pm 0.11$ & $-0.04 \pm 0.08$ & $90.58 \pm 20.59$ \\
Clorox/Calgon & $0.33 \pm 0.12$ & $-0.03 \pm 0.15$ & $91.77 \pm 10.61$ \\
Distilled water & $0.31 \pm 0.11$ & $-0.01 \pm 0.03$ & $103.54 \pm 5.84$ \\
\hline
\end{tabular}


$\mathrm{NaOCl}$ solutions, simulating a 180 -day period. The research hypothesis was rejected because immersion in $\mathrm{NaOCl}$ solutions after the tested time does not influence the properties of microwave-polymerized acrylic resin.

The daily short immersion of the removable prosthesis in commercial bleaching agents is indicated for domestic use, because it is an inexpensive and simple hygiene method (13). Such method is recommended for denture hygiene, as long as it is able to decrease the pathogenicity of the microorganisms present on its surface (14). This way, chemicals can reduce the clinical signs of denture stomatitis and improve biofilm control $(16,17)$. Combining $\mathrm{NaOCl}$ solutions with a water softener solution (i.e. Calgon) is also recommended for daily hygiene of complete dentures $(2,16)$. The rationale for adding a water softener is the improvement in the removal of heavier deposits or stains (2) by means of chelating action.

The physical and mechanical properties of the acrylic resin tested were not influenced by the solutions of $\mathrm{NaOCl}$. An important factor to be considered is the temperature used in the solutions. Many authors reported whitening of the acrylic resin when using high temperatures $(4,5)$, which is associated with reduced flexural strength (4). Both immersion and tests were carried out at room temperature, which is fairly lower than the glass transition temperature of acrylic resins. Thus, any difference among groups would be a consequence of chemical interactions $(4,5)$.

Different methods of polymerization of the acrylic resins can alter their physical and mechanical properties (18). In this study, a microwave-polymerized acrylic resin was tested because of its broad use for complete denture fabrication. Barbosa et al. (19) evaluated the influence of the microwave polymerization in the flexural strength of a denture base resin, and concluded that microwave-polymerized materials presented higher means for flexural strength.

In relation to color stability, the results are in accordance with those of McNeme et al. (3) and Polyzois et al. (12). Both studies did not find color changes in acrylic resins after the use of $\mathrm{NaOCl}$ in different concentrations $(1 \%, 5.25 \%, 0.525 \%)$, although the immersion time was shorter ( $72 \mathrm{~h}$ and 7 days, respectively). Higher concentrations such as $5.25 \%$, however, cause whitening after 7 days of immersion (8). Chemical reaction between $\mathrm{NaOCl}$ and colorants of the resin could not be discarded in this study. Nevertheless, it seems that short-term daily immersions during 180 days would not degrade the colorants significantly. It can be stated that the minor color changes detected were mainly associated with water sorption (5), instead of chemical bleaching.

The assessment of surface roughness discloses no deleterious effect of the $\mathrm{NaOCl}$ solutions compared with water alone. According to Azevedo et al. (15), no alterations of the surface roughness of acrylic resin after immersion in $1 \% \mathrm{NaOCl}$ among other solutions were found, after 7 days. The results of the present study are also in accordance with those of Lima et al. (20), with no alterations in surface roughness of acrylic resin after immersion in $0.5 \% \mathrm{NaOCl}$ among other cleansers. $\mathrm{NaOCl}$ is able to cause structural changes in the polymeric matrix of acrylic resins (4). Such effect could result in softening of the surface and, as a consequence, roughness would be expected to increase. However, it seems that the simulated cleansing regimen is innocuous for microwave-polymerized denture bases. This can be reinforced by the fact that, contrary to color stability, not even water sorption seems to modify surface roughness.

Flexural strength results are in accordance with Pavarina et al. (9), who showed that $1 \% \mathrm{NaOCl}$ did not affect the flexural strength of acrylic resins, although the time of immersion was shorter. Orsi and Andrade (10) also reported that the flexural strength was not affected after immersion in $\mathrm{NaOCl}(1 \%, 2.5 \%$ and $5.25 \%)$, although the times of immersion were 10 and $60 \mathrm{~min}$. As for the surface, absorbed $\mathrm{NaOCl}$ can also degrade the bulk of an acrylic resin (4). It seems that the tested regimen was not able to cause significant deleterious effects on the flexural strength, as found by the other studies $(9,10)$.

Considering the methodological limitations of this study, no simulation of the denture inside the oral cavity was conducted, i.e. immersion in saline solution. Such simulation would remove chemical substances from the specimens and thus any possible chemical degradation would be the same or smaller. This way, a different result would not be expected by means of a simulated denture use period or a clinical study. Moreover, it cannot be stated that $\mathrm{NaOCl}$ does not degrade denture bases acrylic resins by means of the present results. Higher concentrations are able to damage the resins (8). However, this study aimed to simulate short periods of immersion, as done for effervescent tablets. Future studies should investigate a longer time of immersion (overnight) in $\mathrm{NaOCl}$ solutions with different 
concentrations and its effectiveness to disinfect the acrylic resin.

Under the conditions of this study, it may be concluded that immersion in $0.5 \%$ and $1 \% \mathrm{NaOCl}$ solutions for $20 \mathrm{~min}$ does not influence the color stability, surface roughness and flexural strength of microwavepolymerized acrylic resin. The short immersion time tested during 180 days could be recommended for the patients, but further studies are necessary to investigate the solutions during a longer immersion period.

\section{RESUMO}

Este estudo avaliou a estabilidade de cor, rugosidade superficial e resistência à flexão de resina acrílica polimerizada por microondas após desinfecção em hipoclorito de sódio, simulando 20 min de desinfecção diária durante 180 dias. Quarenta espécimes circulares $(15 \times 4 \mathrm{~mm})$ e 40 retangulares $(65 \times 10 \times 3 \mathrm{~mm})$ foram preparados em resina acrílica polimerizada por microondas (Onda-Cryl). As amostras foram imersas em hipoclorito de sódio a $0,5 \%$, hipoclorito de sódio a $1 \%$, Clorox/Calgon e água destilada (controle). Medidas de cor foram determinadas por um espectrocolorímetro portátil. Três linhas paralelas, separadas por $1,0 \mathrm{~mm}$, foram registradas em cada amostra antes e depois dos procedimentos de imersão para analisar a rugosidade superficial. A resistência à flexão foi medida utilizando um teste de flexão por 3 pontos em uma máquina universal de ensaios com uma célula de carga de $50 \mathrm{Kgf}$ e uma velocidade de $1 \mathrm{~mm} / \mathrm{min}$. Os dados foram analisados estatisticamente por ANOVA e teste de Tukey $(\alpha=0,05)$. Não houve diferença estatisticamente significante $(p>0,05)$ entre as soluções para cor, rugosidade superficial e resistência à flexão. Pode-se concluir que a imersão em soluções de hipoclorito de sódio, simulando um uso diário de curta duração durante 180 dias, não influenciou a estabilidade de cor, rugosidade superficial e resistência à flexão de resina acrílica polimerizada por microondas.

\section{ACKNOWLEDGEMENTS}

The authors would like to thank the São Paulo State Foundation (FAPESP; grants 06/56805-3, 06/54119-5, 06/05694-7) and the Bazilian National Council for Scientific and Technological Development (CNPq; 117753/2007-6) for the financial support.

\section{REFERENCES}

1. Montagner H, Montagner F, Braun KO, Peres PE, Gomes BP. In vitro antifungal action of different substances over microwavedcured acrylic resins. J Appl Oral Sci 2009;17:432-435.

2. Moore TC, Smith DE, Kenny GE. Sanitization of dentures by several denture hygiene methods. J Prosthet Dent 1984;52:158-163.
3. McNeme SJ, Von Gonten AS, Woolsey GD. Effects of laboratory disinfecting agents on color stability of denture acrylic resins. J Prosthet Dent 1991;66:132-136.

4. Robinson JG, McCabe JF, Storer R. Denture bases: the effects of various treatments on clarity, strength and structure. J Dent 1987; 15:159-165.

5. Devlin H, Kaushik P. The effect of water absorption on acrylic surface properties. J Prosthodont 2005;14:233-238.

6. Jagger DC, Al-Akhazami L, Harrison A, Rees JS. The effectiveness of seven denture cleansers on tea stain removal from PMMA acrylic resin. Int J Prosthodont 2002;15:549-552.

7. Berger JC, Driscoll CF, Romberg E. Surface roughness of denture base acrylic resins after processing and after polishing. J Prosthodont 2006;15:180-186.

8. Ma T, Johnson GH, Gordon GE. Effects of chemical disinfectants on the surface characteristics and color of denture resins. J Prosthet Dent 1997;77:197-204.

9. Pavarina AC, Machado AL, Giampaolo ET, Vergani CE. Effects of chemical disinfectants on the transverse strength of denture base acrylic resins. J Oral Rehabil 2003;30:1085-1089.

10. Orsi IA, Andrade VG. Effect of chemical disinfectants on the transverse strength of heat-polymerized acrilic resins submitted to mechanical and chemical polishing. J Prosthet Dent 2004;92:382388.

11. Sato S, Cavalcante MR, Orsi IA, Paranhos HFO, Zaniquelli O. Assessment of flexural strength and color alteration of heatpolymerized acrylic resins after simulated use of denture cleansers. Braz Dent J 2005;16:124-128

12. Polyzois GL, Yannikakis SA, Zissis AJ, Demetriou PP. Color changes of denture base materials after disinfection and sterilization immersion. Int J Prosthodont 1997;10:83-89.

13. Keyf F, Güngör T. Comparison of effects of bleach and tablet on reflectance and surface changes of a dental alloy used for removable partial dentures. J Biomater Appl 2003;18:5-14.

14. Barnabé W, Mendonça Neto T, Pimenta FC, Pegoraro LF, Scolaro JM. Efficacy of sodium hypochlorite and coconut soap used as disinfecting agents in the reduction of denture stomatitis, Streptococcus mutans and Candida albicans. J Oral Rehabil 2004;31:453459.

15. Azevedo A, Machado LA, Vergani CE, Giampaolo ET, Pavarina AC, Magnani R. Effect of disinfectants on the hardness and roughness of reline acrylic resins. J Prosthodont 2006;15:235-242.

16. Ghalichebaf M, Graser GN, Zander HA. The efficacy of denture cleansing agents. J Prosthet Dent 1982;48:515-520.

17. Watkinson AC, McCreight MC, Wornock DW. Prevalence and persistence of different strains of Candida albicans in treatment of denture stomatitis. J Prosthet Dent 1985;53:365-366.

18. Lai CP, Tsai MH, Chen M, Chang HS, Tay HH. Morphology and properties of denture acrylic resins cured by microwave energy and conventional water bath. Dent Mater 2004;20:133-141.

19. Barbosa DB, Souza RF, Pero AC, Marra J, Compagnoni MA. Flexural strenght of acrylic resins polymerized by different cycles. J Appl Oral Sci 2007;15:424-428.

20. Lima EM, Moura JS, Del Bel Cury AA, Garcia RC, Cury JA. Effect of enzymatic and $\mathrm{NaOCl}$ treatments on acrylic roughness and on biofilm accumulation. J Oral Rehabil 2006;33:356-362.

Accepted September 16, 2009 